\title{
GAMBARAN PENGETAHUAN IBU MENYUSUI TENTANG CARA MENYIMPAN ASI YANG BENAR DI BPM SURYATI PALEMBANG TAHUN 2016
}

\author{
Desi Ulandari \\ Program Studi D III Kebidanan STIKES ‘Aisyiyah Palembang \\ Jl. Kol H. Burlian M. Husin Kel. Karya Baru Kec. Alang-alang Lebar Km 7,5 Palembang \\ Email: desi.ulandari86@gmail.com
}

\begin{abstract}
Abstrak
Tujuan penelitian ini untuk mengetahui gambaran pengetahuan ibu menyusui tentang cara menyimpan ASI yang benar di BPM Suryati Palembang tahun 2016. Penelitian menggunakan metode deskriptif analitik dengan pedekatan "cross sectional". Pengambilan sampel dilakukan dengan metode accidental sampling dengan umlah sampel penelitian sebanyak 31 responden. Analisis data menggunakan analisis univariat dan analisis bivariat dengan menggunakan uji chi square. Penelitian ini dilakukan pada bulan Desember 2016 - Januari 2017. Hasil penelitian diketahui 27 responden (87,1\%) cara menyimpan ASI yang benar, 24 responden (77,4\%) memiliki pengetahuan baik.
\end{abstract}

Kata Kunci: Cara Menyimpan ASI, Pengetahuan

\begin{abstract}
The infants who are given the formula milk have possibility to be hospitalized because of the bacterial infection. It is fourfold more often than infants why are given exclusive ASI. The purpose of this research is to know the description of the knowledge of the suckling mothers about the way of storing ASI properly at BPM Suryati Palembang year 2016. The research uses analytical descriptive method with the approach "cross sectional". Samples taking is done by using accidental sampling method with the amount of the research samples as many as 31 respondents. Data analysis uses univariat and bivariat analysis wits using chi square test. This research was held on December 2016 - January 2017. The result of the research is known that 27 respondents $(87,1 \%)$ haven't known the way of storing ASI properly and 24 respondents $(77,4 \%)$ have good knowledge.
\end{abstract}

Keywords : How to store breast milk, Knowledge 


\section{PENDAHULUAN}

ASI dalam jumlah cukup merupakan makanan terbaik pada bayi dan dapat memenuhi kebutuhan gizi bayi selama 6 bulan pertama. ASI merupakan makanan alamiah yang pertama dan utama bagi bayi sehingga dapat mencapai tumbuh kembang yang optimal (Walyani, 2015).

Bayi yang sehat, lahir dengan membawa cukup cairan di dalam tubuhnya. Kondisi ini akan tetap terjaga bahkan dalam cuaca panas sekalipun, bila bayi diberi ASI secara eksklusif siang dan malam. Namun sayangnya, kebiasaan memberi cairan pada bayi selama 6 bulan pertama, yaitu periode pemberian ASI eksklusif masih dilakukan dibanyak belahan dunia, yang berakibat buruk pada gizi dan kesehatan bayi (Maryunani, 2015).

Menurut World Health Organization (WHO) pada tahun 2013 terdapat 1-15 juta bayi di dunia yang meninggal karena tidak di beri ASI eksklusif. ASI sangat bermanfaat mengurangi sakit yang berat. Bayi yang di beri susu formula berkemungkinan untuk di rawat di rumah sakit karena infeksi bakteri hampir 4 kali lebih sering dibanding bayi yang di beri ASI ekslusif. (Iskandar, 2014)

Menurut ahli gizi anak United Nation Childrens Fund (UNICEF), Felicity Savage King mengatakan, pemberian ASI eksklusif akan berdampak pada sistem endokrin yakni pelepasan hormon prolaktin dan oxitosin yang akan mempengaruhi sikap dan pola asuh ibu terhadap perkembangan emosional dan otak anak. Sehingga anak-anak yang tidak mendapatkan ASI cenderung lebih beresiko terkena depresi dan masalah emosional lainnya. (Iskandar, 2014)

UNICEF menyatakan, sebanyak 30.000 kematian bayi di Indonesia dan 10 juta kematian anak Balita di dunia pada tiap tahunnya, bisa dicegah melalui pemberian ASI (Air Susu Ibu) secara eksklusif selama enam bulan sejak tanggal kelahirannya, tanpa harus memberikan makanan serta minuman tambahan kepada bayi (Mawardi, 2012)
Berdasarkan Survei Demografi dan Kesehatan Indonesia (SDKI) tahun 20092013 pemberian ASI pada bayi berumur 2 bulan hanya $64 \%$. Persentase ini menurun dengan jelas menjadi $45 \%$ pada bayi berumur 2-3 bulan dan $14 \%$ pada bayi berumur $4-5$ bulan. Hanya $40 \%$ bayi mendapatkan ASI dalam satu jam kelahiran sedangkan pemberian ASI eksklusif di kota Surabaya dari 15.983 bayi berusia 6 bulan, hanya 3.302 bayi diantaranya yang mendapat ASI atau sekitar $20,66 \%$ bayi mendapat ASI secara eksklusif (Ririn, 2014).

Berbagai faktor yang mempengaruhi pemberian ASI secara eksklusif diantaranya adalah faktor internal ibu yaitu pendidikan, pengetahuan, sikap/perilaku, psikologis, fisik ibu dan faktor emosional dan faktor eksternal yaitu peranan ayah, perubahan sosial budaya seperti ibu-ibu yang bekerja, kurangnya petugas kesehatan, meningkatnya promosi susu kaleng sebagai pengganti ASI dan pemberian informasi yang salah (Muchlis, 2012)

Cakupan pemberian ASI eksklusif di Provinsi Sumatera Selatan pada tahun 2014 sebesar 63,44\%, pada tahun 2015 cakupan pemberian ASI eksklusif sebesar $61 \%$ dan pada tahun 2015 cakupan pemberian ASI eksklusif sebesar 66,70\% (Dinkes Prov. Sumsel, 2015).

Menurut data Dinas Kesehatan Kota Palembang, jumlah bayi yang diberi ASI Eksklusif pada tahun 2013 adalah sebesar $50,51 \%$ tahun 2014 jumlah bayi yang diberi ASI Eksklusif sebesar 60,14\%, pada tahun 2015 jumlah bayi yang diberi ASI Eksklusif meningkat menjadi $73,57 \%$, angka ini juga masih belum mencapai target Dinas Kesehatan Kota Palembang 80\%. Cakupan ini masih jauh di bawah target pencapaian pemberian ASI ekslusif Indonesia yaitu $80 \%$ (Dinkes Kota Palembang, 2015).

Data yang diperoleh dari BPM Suryati Palembang tahun 2013, jumlah bayi sebanyak 520 orang, diantaranya yang mendapatkan ASI secara ekslusif sebanyak 393 orang. Tahun 2014 jumlah bayi 
sebanyak 433 orang, diantaranya yang mendapatkan ASI secara Ekslusif sebanyak 313 orang dan pada tahun 2015 jumlah bayi sebanyak 459 bayi yang mendapatkan ASI eksklusif sebanyak 407 orang (Profil BPM Suryati, 2015).

Berdasarkan uraian latar belakang diatas, peneliti tertarik meneliti tentang "Gambaran Pengetahuan Ibu Menyusui tentang Cara Menyimpan ASI yang Benar di BPM Suryati Palembang tahun 2016".

\section{METODE PENELITIAN}

Jenis penelitian ini menggunakan metode deskriptif analitik dimana variabelvariabel independen dan variabel dependen untuk diketahui gambaran atau karakteristiknya. Populasi penelitian ini adalah semua ibu menyusui yang datang ke BPM Suryati Palembang tahun 2016. Sampel pada penelitian ini adalah ibu yang menyusui pada bayi di BPM Suryati Palembang tahun 2016. Pengambilan sampel pada penelitian ini akan dilakukan dengan cara non probability sampling dengan metode accidental sampling. Penelitian ini dilaksanakan di BPM Suryati Palembang yang beralamat di Jl. Pangeran Antarasari No. 142 RT.03 Kel. 13 Ilir Kec. Ilir Timur I Palembang. Penelitian ini dilaksanakan pada bulan Desember 2016 Januari 2017. Pada penelitian ini menggunakan data primer yang diperoleh dari hasil pengisian kuesioner yang dilakukan oleh responden yaitu ibu menyusui. Penelitian ini menggunakan teknik pengumpulan data dengan cara wawancara dan observasi. Analisa data yang dilakukan untuk mengetahui distribusi frekuensi dari tiap-tiap variabel, dari variabel independen (pengetahuan) dan variabel dependen (penyimpanan ASI yang benar).

\section{HASIL PENELITIAN DAN PEMBAHASAN}

\section{Analisis Univariat}

Berdasarkan hasil penelitian

diketahui bahwa dari 31 responden menjawab pernyataan tentang cara menyimpan ASI yang benar sebanyak 27 responden $(87,1 \%)$ yang benar dan 4 responden $(12,9 \%)$ menjawab pernyataan tentang cara menyimpan ASI yang tidak benar, responden berpengetahuan baik tentang cara menyimpan ASI yang benar sebanyak 24 responden $(77,4 \%)$ dan responden berpengetahuan kurang tentang cara menyimpan ASI yang benar sebanyak 7 responden $(22,6 \%)$.

Tabel 1. Distribusi Frekuensi Cara Menyimpan ASI yang Benar dan Pengetahuan di BPM Suryati Palembang Tahun 2016

\begin{tabular}{ccc}
\hline $\begin{array}{c}\text { Cara menyimpan } \\
\text { ASI yang Benar }\end{array}$ & f & \% \\
\hline Ya & 27 & 87,1 \\
\hline Tidak & 4 & 12,9 \\
\hline Total & 31 & 100 \\
\hline Pengetahuan & $\mathbf{f}$ & $\boldsymbol{\%}$ \\
\hline Baik & 24 & 77,4 \\
\hline Kurang & 7 & 22,6 \\
\hline Total & 31 & 100 \\
\hline
\end{tabular}

Berdasarkan pengisian kuesioner yang dilakukan oleh responden diketahui jawaban yang paling banyak benar terdapat pada soal nomor 6 dan 7 yaitu tentang ibu tidak perlu mencuci tangan sebelum memerah ASI dan kontainer harus dicuci dengan air panas dan sabun sebelum dipakai. Ibu banyak tidak setuju dengan pernyataan nomor karena yang mengatakan tidak perlu mencuci tangan sebelum memerah ASI karena kebersihan tangan perlu dijaga karena bila tangan ibu kotor saat memerah ASI dapat menyebabkan ASI menjadi tidak higienis sehingga menyebabkan bayi sakit seperti terkena diare. Selanjutnya pada jawaban nomor 7 ibu mengatakan kontainer tempat penyimpanan ASI perlu dicuci dengan air panas dan sabun tujuannya adalah untuk menghilangkan kuman, bakteri yang ada di tempat tersebut sehingga tempat tersebut menjadi higienis untuk menyimpan ASI.

Jawaban responden yang paling banyak salah terdapat pada nomor 14 yaitu saat bayi kenyang simpanlah sisa ASI untuk 
pemberian berikutnya. Responden setelah menyusui bayi sampai kenyang tidak langsung memerah ASInya dan menyimpannya karena responden memerah ASI pada saat sebelum berangkat bekerja dan pada saat responden di dekat bayi tidak pernah memerah ASI bila bayi sudah diberi ASI dengan kenyang.

Berdasarkan penelitian Amran (2012) tentang gambaran pengetahuan ibu tentang menyusui dan dampaknya terhadap peberian ASI eksklusif, didapatkan hasil 24 responden $(6 \%)$ yang berpengetahuan baik tentang cara menyimpan ASI yang benar.

Berdasarkan uraian diatas peneliti berpendapat bahwa semakin baik pengetahuan ibu maka ibu akan semakin baik cara penyimpanan ASI, begitu juga sebaliknya pengetahuan membuat ibu kurang memahami tentang cara menyimpan ASI yang benar.

\section{KESIMPULAN}

Dari hasil penelitian yang telah diuraikan sebelumnya, maka dapat ditarik kesimpulan sebagai berikut: distribusi frekuensi dari 31 responden sebanyak 27 responden $(87,1 \%)$ cara menyimpan ASI yang benar dan 4 responden $(12,9 \%)$ cara menyimpan ASI yang tidak benar. Distribusi frekuensi dari 31 responden berpengetahuan baik sebanyak 24 responden $(77,4 \%)$ dan responden berpengetahuan kurang sebanyak 7 responden $(22,6 \%)$.

\section{SARAN}

\section{Bagi BPM Suryati Palembang}

Bagi BPM Suryati Palembang diharapkan dapat melakukan penyuluhan tentang cara menyimpan ASI yang benar maupun konseling secara langsung atau membuat spanduk/banner tentang cara penyimpanan ASI yang benar kepada masyarakat agar pengetahuan warga setempat dapat bertambah. Hal ini di tujukan agar masyarakat mempunyai pandangan yang benar mengenai cara menyimpan ASI yang benar.
2. Bagi STIKES 'Aisyiyah Palembang Bagi institusi pendidikan diharapkan dapat meningkatkan penyediaan buku-buku sumber untuk bacaan guna menambah ilmu dan pengetahuan serta dapat digunakan untuk melengkapi referensi kepustakaan yang menunjang penelitian selanjutnya.

3. Bagi Peneliti Selanjutnya

Dari hasil penelitian ini diharapkan bagi peneliti yang akan datang dapat mengembangkan penelitian tersebut dengan menggunakan analisis lain seperti menggunakan analisis bivariat dengan variabel lain misalnya pendidikan, pekerjaan dan status sosial ekonomi yang berhubungan tentang cara menyimpan ASI yang benar serta melakukan penelitian dengan waktu yang lebih lama sehingga hasil penelitian lebih akurat sehingga dapat menambah pengetahuan bagi para ibu untuk menyimpan ASI yang benar.

\section{DAFTAR PUSTAKA}

Amran Y. 2012. Gambaran Pengetahuan Ibu Tentang Menyusui Dan Dampaknya Terhadap Peberian Asi Eksklusif. Jurnal Univ. Baiturrahmah Padang.

Dinkes Kota Palembang.2014. Profil Kesehatan Kota Palembang. Palembang. Dinkes Kota Palembang.

Dinkes Sumsel. 2014. Profil Kesehatan Provinsi Sumatera Selatan. Palembang. Dinkes. Pemprov.

Iskandar. 2014. ASI Sehat Untuk Bayi. (Online) (http://perkembangpemberian-ASI-diIndonesia)

Mawardi. 2014. Kampanye ASI untuk Generasi Unggul (Online) at (http://www.jurnalnasional.com)

Maryunani Anik. 2015. Ilmu Kesehatan Anak dalam Kebidanan. Jakarta : Trans Info

Muchlis. 2011. Ketika si Kecil Lahir. Yogyakarta: ANDI

Profil BPM Suryati Palembang.2015.

Ririn. 2012.Seputar Kesehatan Anak. (Online) at http://idai.or.id/ririn/public- 
articles/klinik/asi/2014/1-2-3-menujuasi-eksklusif.html

Walyani Siwi Elisabeth. 2015. Asuhan Kebidanan Pada Masa

Nifas.Yogyakarta: Pustaka Baru. 